\title{
ÉTICA E TEORIAS DA COMUNICAÇÃO: PODER, INTERAÇÕES E CULTURA PARTICIPATIVA
}

\author{
Luis Mauro Sá Martino \& Ângela Cristina Salgueiro Marques \\ Imsamartino@gmail.com; angelasalgueiro@gmail.com \\ Faculdade Cásper Líbero, Universidade Federal de Minas Gerais \\ Belo Horizonte - MG - Brasil Cep. 31330-110
}

\begin{abstract}
ReSUMO
Este texto aborda aspectos das concepções de ética presentes nas principais Teorias da Comunicação, identificando, em algumas de suas proposições epistemológicas, elementos de um ethos. Sublinha-se como essas teorias, além de abordarem processos comunicativos mediados, propõem procedimentos e ações práticas. Em perspectiva histórico-crítica, mapeia-se como noções de poder, capacidades comunicativas e delineamentos do sujeito político, entre outras, são entrelaçadas às enunciações teóricas da área. A análise desenvolve-se ao redor de três perspectivas: (a) assimétrica, com o poder colocado ao lado dos meios de comunicação; (b) simétrica, equivalendo, em espaços diferentes, produtores e receptores; (c) paritária, com intersecção entre ambos em uma cultura da participação. O texto analisa essas três perspectivas nas rupturas e continuidades entre o ético e o epistemológico.
\end{abstract}

\section{Palavras-chave}

Teorias da Comunicação; epistemologia; ética

\section{INTRODUÇÃO}

Uma reflexão que se proponha a abordar aspectos das concepções de ética presentes nas principais Teorias da Comunicação deve considerar, em um primeiro momento, uma ausência de articulações explícitas entre questões teórico-epistemológicas da Comunicação e as problemáticas normativas e deontológicas que configuram valores, comportamentos e práticas discursivas as mais diversas. As Teorias da Comunicação, sua substância conceitual e paradigmática, além das discussões travadas na área e as demandas delas derivadas, aparentam não terem muito pontos de interseção com princípios éticos, ainda que os explorem seja em sua dimensão especificamente voltada para a prática dos profissionais de comunicação (cf. Meyer, 1986; Martino \& Silva, 2013), seja trabalhada do ponto de vista de uma ética comunicativa (Marques, 2011).

Se compararmos, nos cursos universitários de Comunicação, os programas das disciplinas de "Teorias da Comunicação" - voltados para o estudo das chamadas "escolas teóricas" dentro de uma notável dispersão epistemólogica (Martino, 2011, 2012) - e "Ética" ou "Ética e Legislação", no qual se trabalham temas voltados para as questões de caráter profissional (Christofolletti, 2011), é possível que não encontremos muitos pontos de interseção. Espalhadas em momentos diferentes nas matrizes curriculares das habilitações, parecem não manter muitas relações entre si, como se o conhecimento das "teorias", em um momento - geralmente nos períodos iniciais dos cursos - não 
estivesse ligado ao conhecimento das "práticas" e responsabilidades dos profissionais no momento mesmo de sua formação acadêmica.

Dentre as exceções, pode-se assinalar os trabalho de Barros Filho (1995) e Karam (1997; 2005) como aportes nos quais a questão ética é inserida, respectivamente, no contexto de teorias da Comunicação e no âmbito das teorias do Jornalismo ou Semiótica. No entanto, esses estudos sugerem uma apropriação das teorias da Comunicação para o estudo dos temas da ética, sem focalizar especificamente o que poderia ser pensado como uma ética presente nas Teorias da Comunicação, algo sugerido por Signates (2005: 2), quando afirma que, "desde o princípio, o objeto da comunicação é ético e que, portanto, sua definição implica em parâmetros éticos".

Este texto busca delinear algumas das dimensões éticas presentes nas Teorias da Comunicação, procurando observar, dentro de seus principais postulados, quais são as perspectivas que se manifestam para além de eixos paradigmáticos que segmentam e sedimentam nossa reflexão epistemológica e que podem ser entendidas como uma interpretação a respeito do mundo a partir da qual se esperam ou deduzem ações práticas.

A ética, de modo geral, poderia ser examinada a partir de sua primeira sistematização aristotélica, que destaca duas dimensões principais desdobradas da noção de ethos. A primeira diz respeito ao ethos como modo de ser, como modo de vida que garante aos sujeitos o estabelecimento de uma identidade e vínculo com um entorno. É nessa dimensão que definimos quem gostaríamos de ser e refletimos sobre disposições normativas que nos orientam a agir. Em segundo lugar, o ethos como princípio habitual de ação. Nesse sentido, a ética também apresentaria um caráter social e comunicacional, pois embora centrada no indivíduo e em sua reflexão sobre valores e padrões de comportamento, ela é domínio de inter-relação, das relações sociais no interior das instituições e das comunidades.

Diante desse quadro, é possível nos indagarmos acerca de quais problemas éticos são trabalhados nas teorias da Comunicação? Essa pergunta requer alguns cuidados no uso dos conceitos (Bourdieu, 1983), uma vez que a tentativa de construção de uma articulação entre ética e comunicação poderia sugerir uma abertura de foco eventualmente incompatível com o fazer de pesquisa. Aproximar essas duas questões, portanto, requer algumas definições que, embora discutíveis, são necessárias para se partir de algum lugar. Argumentamos que é possível tomar como ponto de partida a apropriação feita de conjuntos teóricos, objetivadas tanto nos livros intitulados "Teoria da Comunicação" quanto àquelas mencionadas nos espaços institucionais e acadêmicos de discussão epistemológica.

Entende-se que enquanto "discurso", pensado como produção articulada de saberes de uma área, as Teorias da Comunicação não se desligam dos espaços de sua produção, nem das concepções a respeito de sociedade, poder, emancipação, participação, autonomia, hierarquias e comportamentos sociais. Nesse sentido, o texto de Bennett (1983) intitulado sintomaticamente "Teorias da Mídia, Teorias da Sociedade" se apresenta como uma possibilidade de trabalho próxima da deste texto, considerando que não há uma Teoria da Comunicação que não se entrecruze, tanto em seus pontos de partida e chegada quanto em seus desenvolvimentos, com uma "Teoria da Sociedade". 
Assim, por "ética" dentro das Teorias da Comunicação, faz-se referência não exatamente ao que poderia ser um estudo sobre as várias "éticas", mas, de maneira próxima a uma meta-observação, procura-se compreender as concepções de um princípio de ação dentro desse quadro de teorias. Uma teoria da comunicação, na medida em que lida com elementos humanos (e também não humanos) em dimensões cognitivas, políticas, sociais e históricas, traz implícita uma série de considerações a respeito do que é o humano, a sociedade, os objetos (visto que nossos fazeres são constantemente entrelaçados às coisas), o que se pode, ou deve, fazer e, sobretudo, como isso se configura no terreno das relações com os meios.

\section{É possível Pensar em uma ética das Teorias de Comunicação?}

Emerge das ambivalências presentes nas Teorias da Comunicação uma abordagem normativo-deontológica decorrente das concepções apresentadas a respeito dos meios de comunicação, sejam de qual tipo forem, e a sociedade com a qual se articulam. Retomando a argumentação de Barros Filho (1995), ao especificar "efeitos", "articulações", "apropriações" e "resistências" na relação entre indivíduos, comunidades e meios de comunicação, se está implicitamente sugerindo, ou deixando subentendido, o que pode ser feito. Não parece ser possível, em alguns casos, separar o diagnóstico de certo prognóstico, ainda que isso não seja feito no sentido de palavras de ordem, manifestos ou incitações à ação. Para o autor, o normativo, nesse sentido, é mais uma decorrência do epistemológico do que propriamente uma causa sui direcionada a normatizar uma prática.

Nas luzes e sombras do discurso epistemológico, sobretudo em sua reflexão sobre a realidade e a prática, estão os elementos constitutivos das prerrogativas de ação normativa, em especial porque se volta, igualmente, para a prática de onde foi haurida. Assim, se o epistemológico se articula com a prática no estabelecimento de conceitos e ideias que servirão de base para o normativo, esse normativo igualmente se articula com a prática, de onde novamente o epistemológico pode retirar alguns de seus elementos de análise.

Em outras palavras, um dos pontos de intersecção entre o ético e o epistemológico revela-se no fato de que a explicação sobre "o que acontece" pode ser igualmente vista como uma proposição sobre "o que se deve fazer a partir disso". Revelam-se no exame das Teorias da Comunicação concepções de um ethos e de formas dissensuais de expressão e interação que inventam modos de ser, ver e dizer, configurando novos sujeitos e novos modos e cenas de enunciação coletiva, naquilo que Esteves (2007) chama de agonística da vida coletiva.

As teorias da comunicação podem nos ajudar a pensar como essas interações são desenhadas eticamente, sobretudo em suas vertentes simétricas e assimétricas, enfocando as posições de produtores e receptores que, investidas de marcas distintivas de poder atribuem aos sujeitos posições sociais, espaços de visibilidade ou invisibilidade, limitações de discurso e de participação nas discussões e decisões coletivas. 
Nesse sentido, é possível, apenas para efeitos de clareza, delinear três tipos principais de perspectivas éticas dentro das teorias da comunicação: (1) teorias que postulam uma assimetria ontológica entre emissores e receptores, deixando à reflexão conceitual a tarefa de denunciar os aspectos de controle, poder e dominação entre esses pólos; (2) uma segunda perspectiva trabalha certa simetria entre mídia e público, entendido como um elemento de fruição/reconstrução da mensagem e, portanto, valorizado também na reflexão teórica como parte ativa do processo; (3) a identificação de uma perspectiva de intersecção entre mídia, indivíduos e sociedade da qual emerge uma ética pautada no exame de formas de poder que, eventualmente exógenas à mídia, manifestam-se nos dispositivos midiáticos e de controle da sociedade.

Vale notar que essas três perspectivas, embora tenham tido desenvolvimentos históricos diacrônicos, apresentam-se dentro dos estudos de Comunicação como perspectivas operacionais ativas nos espaços epistemológicos de pesquisa, nos quais manifestam suas premissas éticas implícitas/explícitas. A cronologia, em outras palavras, não deve ser tomada como sinônimo de sucessão.

\section{A PERSPECTIVA ASSIMÉTRICA}

Uma separação que talvez ajude a problematizar as questões éticas dentro das Teorias da Comunicação consiste em observar certa ambivalência entre o título "Teoria da Comunicação" e a ação de observar as práticas e processos comunicacionais de maneira a extrair daí algum tipo de elaboração conceitual coerente ao que se poderia chamar de "teoria" relacionada, no caso, com a Comunicação. Se pensarmos dessa maneira, a dimensão ética das Teorias pode ser realçada.

Tomando como ponto de partida o critério cronológico, a preocupação teórica com a Comunicação nasce no âmbito de uma compreensão política dos "efeitos" dos meios de comunicação sobre a sociedade no contexto do final da Primeira Guerra Mundial. Os estudos conduzidos pelos chamados "pais fundadores", em particular Lasswell (1927), Merton e Lazarsfeld (1948) de uma das vertentes da Teoria da Comunicação nos Estados Unidos estavam pautados, ainda que não de maneira explícita, pelo objetivo de averiguar como os meios poderiam influenciar as percepções e a cognição dos indivíduos, no que diz respeito à formação de uma "opinião pública" em relação ao conflito. Os estudos pioneiros de Lasswell (1927; 1931; ver também Varão, 2010; Martino, 2012) refletem essa temática na consideração de que um elemento de poder, no caso, a mídia, teria relevância no comportamento político dos cidadãos, influenciando, inclusive, na tomada de decisões eleitorais.

As primeiras teorizações sobre Comunicação pautam-se em uma assimetria presumida entre os meios e os indivíduos que se relacionarem com eles. A noção de "massa" assume aqui um papel fundamental no sentido de classificar a audiência como um todo homogêneo sobre o qual vai se agir. Essa assimetria reserva o poder, em boa parte, aos meios de comunicação pensados em uma dimensão quase que exclusivamente política (mais tarde "ideológica") na qual se relega a segundo plano qualquer consideração 
econômica. O poder dos meios de comunicação se refere, também nesse sentido, a uma perspectiva relacionada ao público: enquanto "massa", o potencial de manipulação - palavra que se tornará cara aos estudos de Comunicação de vários matizes - seria consideravelmente alto, reforçando a assimetria entre o caráter dos cidadãos atingidos por uma mídia potencialmente nefasta.

Em sua vertente crítica, o exame da mídia indicava uma ressonância dessa assimetria em relação aos grupos e indivíduos. Nesse sentido, mesmo um trabalho de fôlego como o capítulo sobre "indústria cultural" na Dialética do Esclarecimento, de Adorno e Horkheimer, ou nos textos posteriores de Adorno sobre o assunto - exclui-se o estudo pioneiro de Horkheimer (2006) intitulado "Arte e Cultura de Massa" - se mantém caudatário de uma perspectiva de desigualdade entre um pólo emissor, nos quais identificam uma poderosa influência da economia política, e um pólo receptor constituido de indivíduos à mercê desse sistema. A segunda geração da Teoria Crítica, representada principalmente por Jürgen Habermas e suas reflexões publicadas na década de 1960, perpetua e amplifica essa dimensão assimétrica, destacando o modo como os meios de comunicação, além de impedirem a emancipação subjetiva, minam a constituição de esferas públicas de livre manifestação de pontos de vista e justificação recíproca de argumentos. Habermas avalia a transformação da imprensa de opinião em imprensa comercial, destacando a perda de seu caráter crítico-reflexivo em favor da "entrada de interesses privados privilegiados na esfera pública." (1984: 218). Para ele, "por um lado é verdade que o âmbito da esfera pública se ampliou com a contribuição da mídia, mas, por outro lado, o equilíbrio de interesses e as intenções do emissor continuam se firmando no bem-comum, sem contudo satisfazê-lo" (1984: 233).

Apesar de Habermas, em 1992, ter revisto sua afirmação de que havia um desenvolvimento linear de um público politicamente ativo para um público recluso numa privacidade perversa - indo de um "público que debate cultura para um consumidor de cultura" (p.438) -, ele nunca deixou de considerar a assimetria entre produtores e receptores de informação, nem o caráter dúbio de ação da mídia no âmbito da formação de esferas públicas. Segundo ele, se de um lado os meios de comunicação conferem visibilidade aos discursos de atores localizados em diferentes arenas comunicativas, de outro, "os profissionais da mídia produzem um discurso de elite, alimentado por atores que disputam entre si por acesso e influência" (2006: 417). Não seria talvez exagero dizer que, com variações críticas, essa posição assimétrica encontrou larga ressonância e descendência nas pesquisas sobre Comunicação, estabelecendo uma série de posicionamentos éticos mais ou menos explícitos no que diz respeito às suas concepções.

Um primeiro tópico seria o postulado de um ser humano indefeso, incapaz de raciocinar por conta própria sem o material dos meios de comunicação. A noção de "alienação", tomada muitas vezes em um sentido vulgar, descolado de sua origem marxiana, é uma das palavras sintomáticas dessa perspectiva. Se o receptor é parte de uma massa desprovida de qualquer auto-consciência de sua condição e, portanto, suscetível de influência considerável no fluxo de suas atividades cotidianas pelas mensagens dos meios de comunicação, talvez não seja de todo errado presumir que ele esteja "desprotegido" 
diante do poder da mídia. Dessa maneira, sua tomada de decisões, seja no âmbito político, seja mesmo no âmbito pessoal, decorreria de um recurso constante às mídias como forma de adquirir algum tipo de conhecimento a respeito do mundo.

Se à mídia caberia dominar e ao receptor obedecer, como a reflexão teórica poderia apontar caminhos e trajetórias outras aos sujeitos, capazes de auxiliá-los em seus projetos identitários, na construção de sua autonomia e de sua cidadania? Parece advir daí o segundo componente de caráter ético vinculado às origens das Teorias da Comunicação.

A ética da teoria, neste caso, seria denunciar esses mecanismos de ação - e a palavra mecanismo é usada intencionalmente no sentido de realçar a perspectiva dessas elaborações teóricas - no auxílio ao indivíduo, seja na proteção do jogo democrático, seja na própria perspectiva de tirá-lo de uma condição de "alienação". Em ambos os casos, parece haver, nos textos de Adorno e Horkheimer, e apesar de sua profunda descrença na capacidade crítica dos sujeitos, uma vaga pressuposição de uma atuação auto-outorgada da teoria no sentido de "libertar" (ou "esclarecer", ou "emancipar") os indivíduos nessas condições.

O convite à reflexão ética que parece emergir dessa perspectiva assimétrica refere-se ao estudo teórico como um elemento responsável por restaurar um eventual "equilíbrio" entre emissores e receptores, entendidos como pólos desiguais de ação. Isso imediatamente poderia levar à pergunta referente à existência de uma postura igualmente assimétrica entre o "público" e as pessoas responsáveis (especialistas, intelectuais) pelo que seria sua "emancipação": parece haver um pressuposto implícito de que o "público" deva ser "libertado", "acordado" ou mesmo "salvo" de potenciais influências dos meios de comunicação e de seus produtos. Ainda assim, emancipar-se pela voz crítica dos intelectuais não conduz o sujeito a "tomar a palavra", a fazer-se interlocutor em cenas de dissenso e a conquistar sua autonomia via troca comunicativa pública. Falar em nome do sujeito ou em sua defesa não significa emancipá-lo e sim assujeitá-lo, torná-lo dependente do discurso e das habilidades de outrem (Spivak, 2010).

De algum modo, Eco (1995) identifica essa postura como representante de uma perspectiva que coloca um desnível entre pesquisadores e "público", ao mesmo tempo em que convida aqueles que compartilham das premissas de pesquisa a se observarem como pertencentes a um lado específico dessa ruptura. Referindo-se às pesquisas críticas, Eco (1995: 42) lembra que "no fundo, o apocalíptico consola o leitor" indicando que o exercício da reflexão em si já o separaria de uma "massa" atingida pela mídia. Em contraposição, o próprio Eco (1997: 12) igualmente menciona que não há separação, diante dos meios de comunicação, entre o "público em geral" e aqueles epistemologicamente preparados para entender essas mensagens.

Ainda no âmbito da emancipação do sujeito, a contribuição de Habermas aponta não no sentido de um esclarecimento vindo dos especialistas, mas oriundo da própria atividade comunicativa dos sujeitos (Marques, 2013). Em sua obra, é o viés pragmático da linguagem que delineia a ética como forma e princípio de ação diante de problemas de ordem moral (Martino \& Marques, 2012). De modo a revelar como, por meio da interação discursiva na esfera pública, os indivíduos poderiam alcançar sua autonomia 
política e chegar a um mútuo entendimento acerca de seus interesses e necessidades, Habermas (1995) procurou esboçar um conjunto de procedimentos normativos, a ética do discurso, capaz de evidenciar como o uso comunicativo da linguagem é capaz de promover emancipação, alcançada pelo desenvolvimento de habilidades comunicativas de exposição argumentativa e justificação pública. A ética do discurso também contempla a busca de uma autocompreensão ética que, inspirada nas considerações de George Herbert Mead, coloca o sujeito constantemente em relação a uma segunda pessoa, em um processo de leitura constante de gestos significativos em busca de reconhecimento e do atendimento às expectativas alheias.

Não podemos deixar de salientar que a conquista da emancipação e da autonomia política, em seu viés relacional, depende de componentes externas aos sujeitos, ou seja, de dimensões comunicativas, sociais e institucionais que, consideradas as assimetrias de poder e de discurso, os permitam participar da vida pública, sendo respeitados, ouvidos e valorizados.

\section{A SIMETRIA POSSÍvel}

Uma segunda postura dentro do que poderia ser chamado de "ética" das Teorias da Comunicação procura modificar a perspectiva anterior no sentido de encontrar um ponto de equilíbrio entre as mensagens produzidas pelos media e os seus destinatários, pensados não mais em termos de uma "massa", mas como "receptores ativos", responsáveis por atribuir sentidos às mensagens dentro de um processo de negociação, mais do que em um modelo estritamente linear-causal.

De saída, nota-se nesse modelo uma preocupação em ressaltar as características próprias do receptor, pensado não como um "alvo" de um processo, mas como um sujeito a ser considerado em suas dimensões históricas, políticas e sociais. Em particular, um sujeito que articula suas vivências e, portanto, suas condições materiais e históricas de percepção - com o conteúdo dos meios e, porque não, com os próprios meios.

Essa segunda perspectiva obteve considerável acolhida na área de Comunicação, sobretudo a partir dos anos 1990 (Jacks, 2010; Jacks \& Escosteguy, 2005). No entanto, seria talvez precipitado buscar na cronologia uma homologia com qualquer desenvolvimento em termos de sucessão ou superação: os modelos assimétricos continuaram não apenas em vigor como também pautaram várias pesquisas na área.

A ideia de "simetria" aqui não significa, em absoluto, uma equivalência institucional de poderes entre os meios de comunicação de massa, caracterizados como grandes conglomerados empresariais, e o receptor. Essa postura parece encontrar os pontos de resistência e mesmo de recusa às mensagens da mídia no âmbito da articulação de sentidos, mostrando um receptor que não apenas está diante dos meios mas também participa de seus significados.

Mais do que ser "protegido" ou "fortalecido" por uma pesquisa que procura denunciar efeitos, a postura, sem perder o viés crítico em relação aos meios de Comunicação, procura entender de que maneira os sujeitos recebem e reconstróem as mensagens 
dos meios. O sujeito passa a ser conhecido como uma fonte de contra-poder, identificado pela teoria como contraponto às mídias de massa. O receptor, em sua rede de interações, parafraseando uma expressão de Martin-Barbero (1997), é o lugar aonde a comunicação propriamente acontece, a despeito de todo o aparato técnico e empresarial das mídias.

A ética do sujeito receptor não o coloca em pé de igualdade institucional, mas parte do princípio de que qualquer mensagem da mídia será reconstruída por indivíduos responsáveis por trazer novos significados, trabalhar com sentidos e estabelecer leituras para além de todo e qualquer contrato previamente estabelecido pelos meios. A dimensão subjetiva destaca-se da perspectiva de massa, e sua ética também é diferente.

Sob uma constelação de influências que inclui desde estudos literários até Gramsci, Foucault e os pós-estruturalistas franceses, a formulação dos Estudos Culturais é uma das primeiras tentativas de trazer uma nova perspectiva na racionalidade prática a respeito dos receptores. Se os estudos de recepção literária de Jauss (2004; ver também Cruz, 1986) - ou, recuando ainda mais, Walter Benjamin (1986) - indicavam uma alternativa para pensar os receptores como parte inalienável do processo de construção da "obra", entendida como algo que existe na medida em que se articula com um leitor/ espectador, são os Estudos Culturais que vão sugerir de maneira objetiva a perspectiva não só de uma resistência, mas também de contra-poder.

Nos trabalhos de alguns de seus fundadores, como Hoggart (1983) e Thompson (1995) já é possível encontrar indícios de uma ética do sujeito receptor, ressaltados principalmente nos trabalhos de Hall (1981). Nesse sentido, textos posteriores de McRobbie (1990) e Lewis (1994) se estabelecem como clássicos para indicar formas de consumo cultural e resistência às mensagens da mídia no momento de sua reelaboração, ou mesmo de uma apropriação crítica das mensagens (Hebdige, 2000) na forma de recriações e apropriações cotidianas (Fiske, 1993a, 1993b).

$\mathrm{Na}$ ética desses desenvolvimentos teóricos, o poder dos meios de comunicação é contrabalançado pelo poder dos vínculos construídos por um receptor multidimensional, que reconstruirá o conteúdo dos meios a partir de suas vivências políticas, históricas e afetivas. Os dois espaços de poder se interseccionam, se completam e se desafiam mutuamente na construção de hegemonias e resistências, em um equilíbrio dinâmico decorrente da simetria identificada, e longe de ser estático em qualquer circunstância.

$\mathrm{Na}$ América Latina há uma série de desenvolvimentos desse ponto de vista objetivado nas várias apropriações da chamada "Teoria das Mediações", elaborada por Martin-Barbero (1997) em seu estudo inicial "Dos Meios às Mediações". Em sua larga descendência, o livro, de algum modo, abriu caminho para que a perspectiva assimétrica "poder das mídias/vulnerabilidade do receptor" se traduzisse em "poder da mídia/ mediações do receptor" como construção de sentidos e significados.

Os trabalhos de Lopes, Borelli e Resende (2004); Baccega (2006); Jacks (1999), Escosteguy (2001) e Jacks e Escosteguy (2005), entre inúmeros outros, sugerem essa tendência ao articular o receptor dentro de uma trama discursiva na qual ele é o protagonista - mas um protagonista igualmente polifônico, dentro de uma perspectiva na qual 
suas múltiplas vinculações, como gênero, faixa etária, classe social, afetos e razões são pensados como ítens indispensáveis na formação não só de sua condição de receptor, mas de sujeito autônomo. Daí a perspectiva ética desse discurso teórico trazer em si uma concepção de sujeito político distante da primeira: no lugar do indivíduo atomizado da massa, encontra-se um indivíduo pertencente a uma comunidade na qual conversa, discute e trabalha os significados. E, nesse processo discursivo, constrói relacionalmente sua autonomia e sua emancipação.

Isso abre espaço para a terceira perspectiva, da ética de um receptor produtivo.

\section{INTERSEÇõES ENTRE PRODUTORES E RECEPTORES NO ÂMBITO DE UMA CUITURA DA PARTICIPAÇÃO}

Uma dimensão teórica da comunicação em especial advoga a prática da co-produção de discursos e sentidos entre agentes midiáticos e agentes sociais: aquela ligada às práticas colaborativas de produção das informações e de construção discursiva de acontecimentos no espaço virtual. Nela, o receptor produz discursos e circula sentidos, trabalhando ao lado de agentes midiáticos para a elaboração conjunta não só de discursos, mas das cenas nas quais esses discursos são encenados e reelaborados, enquanto são também reconfigurados os próprios sujeitos que os enunciam.

A redefinição das alternativas epistemológicas da Comunicação interseccionada com o âmbito das mídias digitais e da cibercultura é uma das razões de extenso debate, no sentido em que indicam as reflexões de Felinto (2011), Pimenta (2011), Rüdiger (2011) e Ferreira (2012), entre outros, podendo um recuo temporal indicar ainda as propostas de Lankshare (2003), Trivinho (2003) e Santaella (2003). As insuficiências postuladas em relação ao modelo emissor-mensagem-receptor, apontadas já em décadas passadas - conferir Beltrán (1978) - recrudescem quando a Teoria da Comunicação se articula com os cenários empíricos da cibercultura.

Se a discussão dessas relações está ainda em elaboração, é possível observar, diante de pesquisas produzidas por pesquisadores em diversas abordagens, a transposição e alteração das questões éticas sugeridas nos ítens anteriores de modo a formular outras questões. Nos ambientes digitais e na cibercultura, na medida em que é discutível a existência de uma relação "emissor-receptor", faria sentido ainda pensar em "simetrias" ou "assimetrias" entre um e outro pólo? Aliás, seria possível de fato falar em "pólos" dentro de uma cultura "participatória", como lembra Jenkins (2008), na qual o domínio das linguagens ultrapassa o monopólio de alguns tipos de comunicação? Na medida em que, no argumento de Shirky (2008), cada indivíduo é um produtor de mídia ou faz parte de um núcleo constitutivo da "inteligência coletiva", na conhecida expressão de Lévy (1999), é questionável se haveria diferenças a serem pensadas. Finalmente, é preciso considerar se as formas de associação e engajamento cívico e/ou político nas redes sociais digitais, como sugerem, entre outros, Merklé (2010), Papacharissi (2009), Marques (2011), Recuero (2012) e Altheman (2012) poderiam ser entendidas como formas de rearticulação de poderes, discursos e ações na sociedade. 
Nesse sentido, as teorias que discutem a comunicação nos ambientes digitais parecem substituir uma dicotomia "simetria/assimetria" por uma outra dinâmica pautada pela conexão e desconexão entre esferas discursivas e atores/interlocutores, ou ainda por uma forma específica de intersecção e articulação. As mensagens da mídia de massa, que não deixam de continuar existindo, não são apenas "reelaboradas" ou "fruídas" por receptores localizados e localizáveis no âmbito de um espaço e tempo determinado, mas são refeitas, ressignificadas, comentadas e reconfiguradas em contextos discursivos absolutamente diversos de sua produção. Mais ainda, essas produções são compartilhadas no espaço das mídias digitais, ganhando repercussão e outros direcionamentos que escapam, pela própria estrutura da rede - e vale, sobre isso, ver os trabalhos de Lemos e Santaella (2011), Leão (1999) e Recuero (2008) -, ao controle das mídias de massa.

Assim, "mídia", "produtores" e "receptores" aglutinam-se de maneira multimodal em inúmeros "nós" da rede, nas quais as relações de poder, adaptadas a uma estrutura rizomática de interação (cf. Deleuze \& Guattari, 1999) se espalham sem ser necessariamente constitutivos de outras ressonâncias no mesmo sentido - em alguma medida, esse é o argumento de Siegel (2005) ao examinar os usos das máquinas e redes digitais.

A "cultura dos fãs", por exemplo, indica não apenas reapropriações dos produtos da Indústria Cultural, mas também a existência de recriações bastante pessoais, em alguns momentos levadas para direções fundamentalmente opostas àquelas de seus produtores, como sugerem os textos de Jenkins (2006; 2008), Santaella (2003; 2005; 2013), Braga (2009), Amaral (2010) ou Auxílio, Martino e Marques (2013).

Por outro lado, a própria interação em rede não escapa às vicissitudes, demandas e constrangimentos da sociedade na qual se insere, incluído nisso os ditames de uma economia de mercado na qual todo e qualquer espaço pode ser objeto de apropriação pelo capital em suas diversas formas. O exame da economia política da Internet e das mídias digitais, bem como de seus elementos cognitivos e de diferenciação social apontam para outra ética. Se não é possível fazer um recenseamento completo de todas essas abordagens, vale ao menos buscar sumarizá-las na medida em que são indicativas de uma ética próxima, em alguns aspectos, da perspectiva assimétrica indicada.

O problema político referente ao controle e à regulação, mas também de crítica à inclusão indicado por Cazeloto (2008) ou Brittos (2010), entre outros, manifesta-se como parte de um pensamento ético que trabalha a Internet em termos de conflito de poderes e, portanto, caudatário de uma postura crítica em relação ao receptor. No mesmo sentido, as pesquisas sobre vigilância, transparência e visibilidade dos indivíduos na Internet, temas tratados nos trabalhos de Bruno (2003), Sibila (2005) e Antoun (2008) sugerem uma postura contrária a do "fortalecimento" dos usuários/receptores/interagentes nos ambientes digitais.

A diluição de fronteiras entre esfera privada e esfera pública, lembra Papacharissi (2008), bem como as formas de solidão geradas nos e pelos ambientes digitais (Turkle, 2005) insinuam um cenário no qual se nota um enfraquecimento dos laços políticos e sociais.

A pretensa igualdade que se instaura entre emissores e receptores nas redes sociais, também esconde desigualdades e assimetrias que se materializam sobretudo no 
desenho discursivo das redes para conversação e debate. Ainda que, no âmbito da Cibercultura, receptores sejam saudados como produtores - não só de informações, narrativas, produtos culturais e bancos de dados, mas também de suas próprias mídias e canais de difusão - os usos sociais dos meios e a produção social de meios têm que vencer barreiras que vão desde as limitações impostas pelas arquiteturas discursivas de plataformas projetadas por poucos até constrangimentos associados a pressões mercadológicas (manutenção de veículos digitais via marketing), institucionais e políticas.

É preciso que tenhamos sempre em mente que a comunicação em rede é intermediada por softwares, por agentes mediadores e condicionada por protocolos que delimitam os conteúdos e os formatos de interação. A assimetria entre interagentes nos espaços virtuais de diálogo coloca em dúvida se os atos de fala e a liberdade comunicativa são minimamente equilibrados nas interações entre os que dominam ou entendem os códigos e os que não entendem (Silveira, 2009). Tais desequilíbrios e constrangimentos nas relações e oportunidades de acesso à rede interconectada dificultam a participação paritária dos indivíduos e a própria constituição de esferas públicas on-line.

A cautela em apontar espaços on-line como esferas públicas deriva do fato de que os diferentes tipos de arquitetura discursiva dos espaços on-line possuem tanto o potencial de constranger quanto de facilitar a abertura, o uso da razão, a criatividade cultural, a auto-organização e a solidariedade. O que está em tela nas trocas conversacionais online é o questionamento das ordens hierárquicas e consensuais nas quais a fala de cada um e o lugar ocupado pelas pessoas são definidos em termos de sua apropriação e de sua adequação a uma função previamente definida como tal (Altheman et al., 2013).

Associada a essa questão, nota-se um recrudescimento das perspetivas de vigilâncias institucionais, das formas de controle e detecção das ações do indivíduo na proliferação do que Agamben (2012) chama de "dispositivos" no sentido mesmo de "proteger" o cidadão, lançando mão de controles e formas de prescrutar a vida individual além de qualquer perspectiva crítica assimétrica. Assim, o cidadão estaria relativamente desprotegido no ambiente das mídias digitais.

Finalmente, mas talvez com menos ênfase política, uma perspectiva teórico-ética dentro da Cibercultura e das mídias digitais postula a existência de um receptor claramente inepto para participar ou gerir esses ambientes, tornando-se presa fácil de sua própria incapacidade, como especificam os apontamentos de Keen (2008). Até certo ponto seria possível observar, neste último ítem, duas perspectivas opostas. Se, em termos éticos, há uma novidade teórica em relação ao apagamento de fronteiras entre emissor e receptor (privilegiando a noção de um usuário gerador de conteúdos), ao mesmo tempo a continuidade e transformações do capitalismo e a proliferação dos dispositivos se apresenta, no terreno teórico, como parte de uma reflexão na qual os poderes se espalham sem se dissolver, e o usuário não estaria muito distante das concepções de uma perspectiva da comunicação de massa. O que não deixaria de ser paradoxal.

\section{CONSIDERAÇões FiNAIS}

A intersecção entre o ético e o epistemológico no âmbito das Teorias da Comunicação 
pode não se apresentar imediatamente à apreensão no âmbito de estudos específicos de uma ou outra parte, pensados sobretudo separadamente. Não obstante, afirma-se como uma possibilidade de retomar a perspectiva de que as teorias da Comunicação, enquanto objetivação de um discurso reflexivo-conceitual a respeito de um "campo da experiência" (Deleuze \& Guattari, 1999), não se desliga, como toda produção de discursos, das condições específicas de sua origem, mediadas por outras circunstâncias de apropriação e reapropriação institucional e epistemológica. A existência do que poderia ser denominada uma "política" na delimitação do espaço conceitual trabalhado pelas Teorias da Comunicação (Ferreira, 2003), bem como nas condições de sua institucionalização (Martino, 2012) sugerem uma das premissas exploradas neste texto.

Apresentamos a perspectiva de que os discursos teóricos sobre Comunicação estão relacionados, de maneira mais ou menos explícita, a pressupostos éticos derivados não apenas de seus vínculos epistemológicos, mas também das proposições apresentadas. Em particular, destacam-se as proposições referentes às relações entre os "meios de comunicação", definição elástica e explorada em suas diferentes formas ao longo do tempo, e os indivíduos e comunidades que, de alguma maneira, estarão ligados a esses meios. As condições histórico-sociais, bem como epistemológicas e conceituais, dessa ligação sugerem as inferências passíveis de análise a partir das quais este texto se estruturou.

Variando de perspectiva no que diz respeito às relações entre emissores, meios e receptores (em uma perspectiva anterior às mídias digitais) ou às perspectivas de reelaboração e participação, no caso do ambiente digital e interacional da Internet, as teorias da Comunicação parecem se delinear não apenas como reflexão a respeito dos elementos conceituais e metodológicos para compreender um fenômeno, mas também de uma normatividade específica que, de certo modo, propõe um protocolo anterior, muitas vezes subjacente, relativo à maneira como se deve observar essas relações entre ambientes, mídias e sociedade.

Em outras palavras, as teorias da Comunicação, ao elegerem seus objetos, métodos e conceitos, mostram quais serão os modos de entendimento propostos em relação às pessoas e às coletividades em suas práticas e vivênvias, mediadas ou não pelos meios.

A identificação conceitual do indivíduo diante de uma tela (e posteriormente inserido em um contexto atravessado por várias mediações), por exemplo, variando entre "massa", "receptor", "fruidor", "usuário" e "fã" não indicam apenas modos de apropriação epistemológico de um fenômeno de interação (mais controlado em uma concepção, mais livre em outra), mas também as perspectivas éticas dessas modalidades no espaço não de uma ética da Comunicação, mas na perspectiva de pensar uma ética das Teorias da Comunicação - não necessariamente para além do epistemológico, mas em sua articulação. É nessa interseção que podemos observar concepções específicas de sujeito, de suas relações políticas, culturais e econômicas e, de certo modo, em escala meta-reflexiva, do próprio lugar das atividades de pesquisa. 


\section{REFERÊNCIAS}

Agamben, G. (2012) "O que é um dispositivo". In__ O que é o contemporâneo? Florianópolis: Argos.

Altheman, F. ; Martino, L. M. S. \& Marques, A. C. S. (2013) "O potencial deliberativo de conversações políticas sobre o Projeto de Lei do Ato Médico no YouTube", Revista Compolitica, v. 1: 45-69.

Amaral, A. (2010) Visões perigosas. Porto Alegre: Sulina.

Antoun, H. (org.) (2008) Web 2.o. Rio de Janeiro: Mauad.

Auxilio, T.; Martino, L. M. S. \& Marques, A. C. S. (2013) "Formas específicas de apropriação cultural dos fãs brasileiros da série Doctor Who", Ciberlegenda, no. 28:110-124

Baccega, M. A. (2006) Televisão e Educação. São Paulo: Ed. Senac.

Barros Filho, C. \& Martino, L. M. S. (2003). O habitus na Comunicação. São Paulo: Paulus.

Barros Filho, C. (1995) Ética na Comunicação. São Paulo.

Beltrán, L. R. (1981) "Adeus a Aristóteles: comunicação horizontal”, Comunicação e Sociedade, no. 6. São Paulo, Cortez/Intercom.

Benjamin, W. (1986) "O que os alemães liam enquanto seus clássicos escreviam". In Documentos de Cultura, Documentos de Barbárie. São Paulo: Cultrix.

Bennett, T. (1983) "Theories of the media, theories of the society". In: Bennett, T.; Curran, J. \& Gurevich, M. (eds.). Culture, Society and the Media. Londres: Methuen.

Bourdieu, P. (1983) Questões de Sociologia. Rio de Janeiro.

Braga, A. (2009) Persona Materno-Eletronicas. Porto Alegre: Sulina.

Brittos, V. (2010) Economia Política da Comunicação. Rio de Janeiro: Mauad.

Bruno, F. et alli. (2010) Vigilância e Visibilidade. Porto Alegre: Sulina.

Cazeloto, E. (2008) Inclusão Digital. São Paulo: Senac.

Christofolletti, R. (2011) "O ensino de ética nos cursos de comunicação", Libero, no. 26:13-26.

Cruz, M. T. (1986) "A estética da recepção e a crítica da razão impura", Revista de Comunicação e Linguagens, $\mathrm{n}^{\circ} \cdot 3$.

Deleuze, G. \& Guattari, F. (1999) O que é a Filosofia. São Paulo: Ed. 34.

Eco U. (1995) Apocalípticos e Integrados. São Paulo: Perspectiva.

Eco, U. (1997) O super-homem de massa. São Paulo: Perspectiva.

Escosteguy, A. C. (2001) Cartografias dos Estudos Culturais. Belo Horizonte: Autêntica.

Esteves, J. P. (1998) A ética da comunicação e os media modernos: legitimidade e poder nas sociedades complexas. Lisboa: Fundação Calouste Gulbenian.

Felinto, E. (2011) "Da Teoria da Comunicação às teorias da mídia.Texto apresentado ao Grupo de Trabalho "Comunicação e Cibercultura", do XX Encontro da Compós. Porto Alegre: UFRGS. 
Ferreira, J. (2003) "Campo acadêmico e epistemologia da comunicação". In: LEMOS, A. etalli (orgs.) Mídia. br. Porto Alegre: Sulina.

Ferreira, J. (2012) "Proposições que circulam sobre a Epistemologia da Comunicação. Texto apresentado ao Grupo de Trabalho "Epistemologia da Comunicação", do XXI Encontro da Compós. Juiz de Fora: UFJF, Junho 2012.

Fiske, J. (1993a) Reading popular culture. Londres: Routledge.

Fiske, J. (1993b) Understanding popular culture. Londres: Routledge.

Habermas J. (1984) Mudança Estrutural da Esfera Pública. São Paulo: Tempo Brasileiro.

Habermas, J. (1992) "Further Reflections on the Public Sphere". In: CALHOUN, Craig (ed.). Habermas and the Public Sphere, p.421-461.

Habermas, J. (1995) "Discourse Ethics: Notes on a Program of Philosophical Justification". In: Benhabib, S. \& Dallmayr, F. (eds.). The Communicative Ethics Controversy. Cambridge: MIT Press, p.60-110.

Habermas, J. (2006) "Political communication in media society: does democracy still enjoy an epistemic dimension? the impact of normative theory on empirical research". Communication Theory, v. 16: $411-426$.

Hall, S. (1980) "Encoding / Decoding". In: Hall, S. etalli. (eds). Culture, Media, Language. Londres: Hutchinson.

Hebdige, D. (2000) Subculture: the meaning of style. Londres: Routledge.

Hoggart, R. (1983) The Uses of Literacy. Londres: Penguin.

Jacks, N. (org). (2010) Meios e Audiências. Porto Alegre: Sulina.

Jacks, N. \& Escosteguy, A. C. (2005) Comunicação e Recepção. São Paulo: Hackers.

Jacks, N. (1999) Querência. Porto Alegre: Ed. UfRGS.

Jauss, H. J. (2004) Towards an aesthetics of reception. Minnesota: Minnesota University Press.

Jenkins, H. (2008) Convergence Culture. Nova York: New York University Press.

Jenkins, H. (2006) Fans, bloggers and gamers: exploring participatory culture. Nova York: NYU Press.

Johnson, S (2010). Cultura da Interface. Rio de Janeiro: Jorge Zahar Editor.

Karam, F. J. (2005) A Ética Jornalística e o interesse público. São Paulo: Summus.

Karam, F. J. (1997) Jornalismo, ética e liberdade. São Paulo: Summus.

Keen, A. (2008) The cult of the amateur. Londres: Nicholas Brealey.

Lasswell, H. (1927) “The Theory of Political Propaganda", The American Political Science Review, V. 21, No. 3 : $627-631$.

Leão, L. (1999) O labirinto da hipermídia. São Paulo: Iluminuras.

Lemos, A. (2002) Cibercultura. Porto Alegre: Sulina. 
Lévy, P. (1999) Cibercultura. São Paulo: Ed. 34.

Lewis, L. A. (1994) The adoring audience. Londres: Routledge.

Lopes, M. I. V.; Borelli, S. \& Resende, R. (2004) Vivendo com a telenovela. São Paulo: Summus.

Marques, A. C. S. (2011) "A ética dos processos comunicativos: discurso, alteridade e espaço público", Verso e Reverso (Unisinos. Online), v. 25:80-91.

Marques, A. C. S. (2013) "A ética do discurso e a formação do sujeito político em Habermas", Cadernos da Escola do Legislativo, v. 15, p. 3-25, 2013.

Martin-Barbero, J. (1997) Dos Meios às Mediações. Rio de Janeiro: Editora UFRJ.

Martino, L. M. S. e SILVA, L. R. (2013) "Paradoxos e fronteiras éticas do jornalismo investigativo", Revista Comunicação Midiática, Vol. 08, no. 1.

Martino, L. C. (2005) "Apontamentos epistemológicos sobre a fundação e a fundamentação do campo comunicacional". In: Capparelli, S. et alli. A Comunicação Revisitada. Porto Alegre: Sulina.

Martino, L. M. (2011) "A influêcia de fatores políticos na formação epistemológica do campo da comunicação no Brasil". Texto apresentado no I Confibercom. São Paulo.

Martino, L. M \& Marques, A. C. S. (2012) "A ética da comunicação a partir da abordagem dos conceitos de interesse e uso da linguagem", Galáxia (PUCSP), v. 23: 139-152.

Martino, L. M. (2009) Teoria da Comunicação. Petrópolis: Vozes.

McRobbie, A. (1994) Postmodernism and popular culture. Londres: Routledge.

Merklé, P. (2010) Sociologie des Réseaux Sociaux. Paris: La Decouverte.

Merton, R. \& Lazarsfeld, P. (1948) "Mass Communication, Popular Taste, and Organized Social Action". In: Bryson, L. The Communication of Ideas. New York: Harper.

Meyer, P. (1986) Ética no jornalismo. Rio de Janeiro: Forense-Universitária.

Papacharissi, Z. (2009) A private sphere. Londres: Polity.

Pimenta, F. J. P. (2011) "Jogos, redes sociais e a crise no campo da Comunicação". Trabalho apresentado no $5^{\circ}$ Simpósio Nacional da ABCiber. Florianópolis: UFSC.

Recuero, R. (2012) A conversação na internet. Porto Alegre: Sulina.

Recuero, R. (2008) Redes Sociais na Internet. Porto Alegre: Sulina.

Rüdiger, F. (2011) "A reflexão teórica em cibercultura e a atualidade da polêmica sobre a cultura de massas", Revista Matrizes, Ano 5, no. or.

Santaella, L. (2003) Navegar no ciberespaço. São Paulo: Paulus.

Santaella, L. (2005) Porque as comunicações e as artes estão convergindo. São Paulo: Paulus.

Santaella, L. (2013) Comunicação ubíqua. São Paulo: Paulus.

Santaella, L. \& Lemos, R. (2011) Redes Sociais Digitais. São Paulo: Paulus. 
Santos, J. R. (1992) Comunicação. Lisboa: Difusão Cultural.

Santos, R. (2003) As Teorias da Comunicação. São Paulo.

Shirky, C. (2008) Here comes everybody. Londres: Penguin.

Sibilia, P. (2008) O show do eu. Rio de Janeiro: Nova Fronteira.

Siegel, L. (2008) Against the machine. Nova York: Serpent's Tail.

Signates, L. (2005) “Encontros de teoria e ética: a relação epistemológica da comunicação e as questões éticas contemporâneas". Trabalho apresentado no XIV Compós. Niterói.

Silveira, S. A. (2009) “Esfera pública interconectada, blogosfera e redes sociais". In: Esfera Pública, Redes e Jornalismo. Rio de Janeiro: E-papers, v.1, p. 70-89.

Spivak, G. C. (2010) Pode o subalterno falar? Belo Horizonte: Editora da UFMG, 2010

Thompson, E. P. (1995) As peculiaridades dos ingleses. São Paulo: Unesp.

Trivinho, E. (2003) O mal-estar na teoria. São Paulo: Quartet.

Turkle, S. (2011) Alone together. Nova York: Basic Books.

$* * *$

Recebido a 18-03-2014

Aceite a 05-05-2014 